\title{
THE EFFECT OF TRADE FACILITATION ON TRADE MARGIN OF 8 ASEAN- CHINA FREE TRADE AREA COUNTRIES (ACFTA): A GRAVITY MODEL APPROACH
}

\author{
Ferdyan Susetyo ${ }^{* 1}$ \\ Rossanto Dwi Handoyo²
}

\author{
1,2Universitas Airlangga, Indonesia
}

\begin{abstract}
Trade facilitation is an effort of simplification and harmonization of international trade procedures. Trade facilitation that manifested in the form of policy packages that aim to reduce trade costs and improve export growth. Export growth can be sourced from the level of diversity of exported goods (extensive margin) and the volume of exported goods (intensive margin). This study aims to analyze the effect of trade facilitation on the extensive and intensive margin of trade eight member countries of ACFTA during the years 2006-2014. Trade facilitation indicators used in this study consisted of exporters and importers port efficiency. This study uses gravity model and estimation techniques Random Effect Model. The results showed that exporter port efficiency have a positive and significant effect on the extensive margin while importer port efficiency has a positive and significant effect on the intensive margin.
\end{abstract}

Keywords: Trade Facilitation, Extensive Margin, Intensive Margin, ACFTA (ASEAN-China Free Trade Area), Gravity Model.

\section{JEL Classification: F13}

To cite this document: Susetyo, F \& Handoyo, R. D, (2016). The Effect of Trade Facilitation on Trade Margin of 8 Asean-China Free Trade Area Countries (ACFTA): A Gravity Model Approach. JDE (Journal of Developing Economies), 1(2), 122-133

\section{Introduction}

Through the export activity, a country can obtain state revenue in the form of foreign exchange. In addition, exports can also be used as a benchmark for the level of competitiveness of domestic products in the international market. The importance of exports to the economy of a country cause each country strive to improve export growth. Trade liberalization is believed to enable to boost economic growth. Trade liberalization aims to make all kinds of trade barriers in the form of both tariff and non-tariff can be reduced oreven eliminated. Trade liberalization encourage the creation of the economic integration between countries. One kind of economic integration is the free trade area (FTA).

One of the free trade area (FTA) that exists is ACFTA (ASEAN-China Free Trade Area). ACFTA is a regional trade cooperation agreements between ASEAN member countries and China. The establishment of ACFTA based on the fact that China is the largest trading partner of ASEAN member countries. In 2014 the total value of trade between ASEAN member countries and China reached 14.5\% (ASEAN Secretariat, 2015). Trade between ASEAN countries and China has increased significantly. Therefore, trade barriers both tariff and non-tariff should be reduced or even eliminated. It aims to maximize the benefits obtained by both parties. 
Export growth may come from increased exports to the country of destination of the old with the quantity as well as higher prices or better known as the intensive margin (intensive margin). Export growth may also come from an increase in exports to the country of destination of new and increased variety of products exported to the country of destination is new or old. This is known as the extensive margin (extensive margin) (Türkcan, 2014).

Thoughts about the extensive and intensive margin started from the difference in the conclusions of the model developed by Armington (1969) and Krugman (1981) in predicting about the source of a country's export growth. The model developed by Armington resulted that the greater size of the economy (economic size) will export volumes more, but not in terms of the type or variety of goods exported (intensive margin). Meanwhile, Krugman stated that countries with greater economic size will export more varies of goods varies in type (extensive margin) (Aldan \& Çulha, 2016)

In performing trading activities, a country often face high trade costs. It seems there isnegative relationship between trade cost and net export. Therefore, it is important for eachcountry to jointly try to reduce the cost of trading. Cost trade consists of two aspects, namely trade costs caused by operational efficiency and cost trade caused, (3) the regulatory environment, and (4) service sector infrastructure (Wilson et al., 2005).

During this time, research on trade facilitation only focus on the effect of trade facilitation on export growth, instead of the extensive margin and intensive margin. Yet export growth was itself actually consists of extensive margin and intensive margin. From a policy perspective, which is important to determine whether the trade facilitation boost export growth through extensive margin or intensive margin.

If trade facilitation increasing export growth through the extensive margin, the implication is the type of goods that are exported are more varied or it can be said the diversification of exports. This condition is theoretically and empirically will have an impact on the creation of a more stable economic growth (Persson, 2013). Conversely, if the trade facilitation increasing export growth through intensive margin then it can be said that an increase in the volume or quantity of goods exported. This indicates that a country is experiencing increased development process to become a developed country (Lee \& Kim, 2018).

In various studies that discussed international trade, the model analysis of the most widely used model is gravity. Gravity model is a model used to see the interaction of trade between countries. The main variables used in gravity model is economic size and the distance between countries. Gravity model indicates that the size of the nation's economy has a positive effect while the distance negatively affect trade flows between countries. According to Chaney (2018) that of distance remains mysterious. I offer an explanation for the role of distance: If ( $i$ use a gravity model of international trade has proved remarkably resilient empirically. The role of economic size and the distance between countries proved to be very stable over time, in different countries, and by using a variety of econometric methods.

This study aims to investigate the effect of trade facilitation on the extensive margin and intensie margin in trade between the eight member countries of ACFTA (Indonesia, Malaysia, Singapore, Thailand, Philippines, Vietnam, Cambodia, and China) with 10 trade partner countries during the years 2006-2014. The measurement of extensive margin and intensive margin done using methods developed by Hummels \& Klenow (2005). Trade facilitation indicators used in this study is the port efficiency. This indicator has been used by Feenstra and $\mathrm{Ma}$ (2014) to determine the influence of trade facilitation to both the trade margin.

So far, studies on the effect of trade facilitation on the extensive margin and intensive margin are not voluminious. Therefore, the study entitled "Effect of Trade Facilitation Of Margin Trading 8 ASEAN-China Free Trade Area: Gravity Model Approach" is expected to contribute to the literature gap. 


\section{Theoretical Basis}

\section{Extensive Margin and Intensive Margin}

In 1969, Armington developed a model that emphasizes on the important role of the intensive margin to explain the growth of exports. In this Armington models assumed that a country is only producing one variety in each category. In addition, internationally traded products differentiated by country of origin of the product. Armington models also assume that each country produces only one type of product in each category and the product is different from the products in the same category from other countries so there is no export growth in the extensive margin (Türkcan, 2014).

On the other side, in 1979-1981 Paul Krugman developed a monopolistic competition model that explains the horizontal intra-industry trade by emphasizing the importance of economies of scale and product differentiation (Appleyard and Field, 2014: 190). Monopolistic competition model proposed by Krugman's assume that each country to specialize in different variations or types of goods. The model also predicts that a country increase exports through the extensive margin is a wider range types of goods. This means that the country exported the same quantity of each variety/type and export with the sameunit price (Türkcan, 2014).

The measurement of extensive and intensive margin margin in this study conducted by using Hummels \& Klenow (2005). According to Baier et al. (2014) which potentially affects an importing country's welfare. This paper: (i, Hummels and Klenow method of measuring the extensive margin (EM) as:

$$
E M_{i j t}=\frac{\sum m \epsilon M_{i j t} X_{w j t}^{m}}{\sum m \epsilon M_{w j t} X_{w j t}^{m}}
$$

where, $X_{\mathrm{wjt}}^{m}$ is the value of exports from the world $(w)$ to country $\mathrm{j}$ for product $m$ in year $t, M_{i j t}$ is a collection of all goods exported by the country $i$ to country $j$ in year $t$ and $M_{\text {wjt }}$ is a collection of all goods exported by world $(w)$ to country $j$ in year t. EM $\mathrm{in}_{\mathrm{ijt}}$ is an extensive margin exports from country $i$ to country $j$ in year $t . E_{i j t}$ value ranges from 0 to 1.

Meanwhile, Hummels \& Klenow (2005) method of measuring the intensive margin (IM) as:

$$
I M_{i j t}=\frac{\sum m \epsilon M_{i j t} X_{i j t}^{m}}{\sum m \epsilon M_{i j t} X_{w j t}^{m}}
$$

where $X_{j i t}^{m}$ is the value of exports from country $i$ to country $j$ for product $m$ in year $t, X_{w j t}^{m}$ is the value of exports from the world $(w)$ country $j$ for product $m$ in year $t$, and $M_{i j t}$ is a collection of all goods exported by state $i$ to state $j$ in year $t . \mathrm{IM}_{\mathrm{ijt}}$ is an intensive margin exports from country $i$ to country $j$ in year $t$. Value $\mathrm{IM}_{\mathrm{ijt}}$ ranges from 0 to 1.

\section{Trade Facilitation}

According to the WTO, trade facilitation is defined as penyederanaan and harmonization of procedures in international trade, where such procedures include activities, practices and formalities that occur in the collection, presentation, communication, and data processing required for the movement of goods in international trade (Moïsé \& Sorescu, 2013).

In a narrow sense, trade facilitation related to a reduction in transaction costs in addition to tariff cuts, which basically include simplification and standardization of customs formalities and administrative procedures relating to international trade (Portugal-Perez \& Wilson, 2012). In the broadest sense, trade facilitation is defined as an attempt was made to improve the environment where commercial transactions take place and reduce the cost of exports andimports. Trade facilitation includes things such as transparency and regulatory policies, good governance, convergence of standards, improvement of information technolo- 
gy services and other infrastructure improvement (Li \& Wilson, 2009).

\section{Gravity Model}

Gravity model is used to analyze empirically the flow pattern of bilateral tradebetween the two countries with geographical distance. Gravity model first developed by Jan Tinbergen in 1962 to analyze the flow of trade between the countries in Europe. Gravity model indicates that the bilateral trade value is a function of the national income of each country and the distance between the two countries (Head, 2003).

In a gravity model, the flow of bilateral trade is determined by three groups of variables: (1) variable gross national income importers who represent the demand side, (2) variable national income country exporters who represents the supply side, (3) a variable distance between the exporters and the state importers as a proxy for the cost of transportation (Appleyard and Field, 2014: 195).

\section{The Relationship between Port Efficiency with Extensive Margin and Intensive Margin}

The relationship between trade facilitation with the extensive and intensive margin margin can be seen from the model Melitz. Melitz models predict that the decline in variable costs will increase the extensive margin because it allows new firms and less productive to be able to enter the export market. Meanwhile, a decrease in variable costs, enables the existing exporters to increase the volume of sales of goods for export (intensive margin).

Dennis \& Shepherd (2011) say that the more productive company owned by a country, the more varied types of goods exported by the country. It was based on the assumption Melitz which states that each company produces different types of goods. Therefore, increased trade facilitation can cause improvement of extensive margin. Instead, according to Türkcan (2014), a decrease in trade costs caused by increased trade facilitation can make it easier for existing exporters to increase their sales volume (intensive margin).

\section{The relationship between GDP per Capita with Extensive Margin and Intensive Margin}

GDP per capita is a proxy measure of a country's economy. GDP per capita represents the level of income earned by individuals in a country. The level of GDP per capita of a country can affect demand for commodities produced by other countries. In addition, the level of GDP per capita of a country can also affect the ability of production of a country.

According to Chaney (2018) that of distance remains mysterious. I offer an explanation for the role of distance: If ( $i$, if the size of the economy of a country exporters have increased the number of companies that exist in the country will increase. That caused the country's production levels also increased. Conversely, if there is an increase in the economic size of a country, the importer of the country's total imports also increased. An increase in total imports was caused by increased demand for commodities produced by other countries.

\section{The relationship between Population with Extensive Margin and Intensive Margin}

Population is one of the proxies used to determine the size of the economy (economic size) of a country. The population can affect the growth of exports through the two sides of the demand side and the supply side. On the demand side, population size indicates the increase in domestic demand.

Meanwhile, on the supply side, an increase in population in a country represents an increase in the number of workers (Salvatore, 2014: 190). This causes the level of the company's production in the country increased. Assuming that each company produces different types of goods, the diversity of the types of goods produced is increasing. It causes the level of diversity of types of goods exported also increased. 


\section{The relationship between Distance with Extensive Margin and Intensive Margin}

The farther a distance between the two countries indicate that the greater the transport costs to be incurred so that trading costs are higher (Dutt et al., 2013). According to the model Melitz, which leads to high trade costs only a few companies that enter into the export market. Assuming that each company produces different types of goods, the greater the distance causes more extensive low level of margin. Meanwhile, the greater the distance it will also cause increasingly low volume of goods exported (intensive margin).

\section{Analysis Model}

Analysis model used in this study is the gravity model using panel data regression. Model analysis in this study refers to the model of previous research originating from Feenstra \& Ma (2014) which has been modified. The regression equation for the extensive margin is as follows:

$$
\begin{aligned}
\ln \left(E M_{i j t}\right)= & \beta_{0}+\beta_{1} \ln \left(P E_{i t}\right)+\beta_{2} \ln \left(P E_{j t}\right)+\beta_{3} \ln \left(G D P P C_{i t}\right)+\beta_{4} \ln \left(G D P P C_{j t}\right)+ \\
& \beta_{5} \ln \left(P O P_{i t}\right)+\beta_{6} \ln \left(P O P_{j t}\right)+\beta_{7} \ln \left(D I S T_{i j}\right)+\varepsilon_{i t}
\end{aligned}
$$

Meanwhile, the regression equation for the intensive margin is as follows:

$$
\begin{aligned}
\ln \left(I M_{i j t}\right)= & \beta_{0}+\beta_{1} \ln \left(P E_{i t}\right)+\beta_{2} \ln \left(P E_{j t}\right)+\beta_{3} \ln \left(G D P P C_{i t}\right)+\beta_{4} \ln \left(G D P P C_{j t}\right)+ \\
& \beta_{5} \ln \left(P O P_{i t}\right)+\beta_{6} \ln \left(P O P_{j t}\right)+\beta_{7} \ln \left(D I S T_{i j}\right)+\varepsilon_{i t}
\end{aligned}
$$

Note:

$\begin{array}{ll}E_{\mathrm{ijt}} & : \text { Extensive margin from country } \mathrm{i} \text { to country } \mathrm{j} \text { in year } \mathrm{t} \\ \mathrm{IM}_{\mathrm{ijt}} & : \text { Intensive margin from country } \mathrm{i} \text { to country } \mathrm{j} \text { in year } \mathrm{t} \\ \mathrm{PE}_{\mathrm{it}} & : \text { Port efficiency index of country } \mathrm{i} \text { in year } \mathrm{t} \\ \mathrm{PE}_{\mathrm{jt}} & : \text { Port efficiency index of country } \mathrm{j} \text { in year } \mathrm{t} \\ \mathrm{GDPPC}_{\mathrm{it}} & : \text { Gross Domestic Product per Capita country } \mathrm{i} \text { in year } \mathrm{t} \\ \mathrm{GDPPC}_{\mathrm{jt}} & : \text { Gross Domestic Product per Capita country } \mathrm{j} \text { in year } \mathrm{t} \\ \mathrm{POP}_{\mathrm{it}} & : \text { Population of country } \mathrm{i} \text { in year } \mathrm{t} \\ \mathrm{POP}_{\mathrm{jt}} & : \text { Population of country } \mathrm{j} \text { in year } \mathrm{t} \\ \mathrm{DIST}_{\mathrm{ij}} & : \text { Distance between country i to country } \mathrm{j} \text { in year } \mathrm{t} \\ \beta_{0} & : \text { Constants } \\ \beta_{1}-\beta_{7} & : \text { Regression coefficient } \\ \varepsilon_{i t} & : \text { Residual value (error term) }\end{array}$

\section{Research Methodology}

This study uses a quantitative approach with the aim of analyzing the effect of trade facilitation on the extensive margin and intensive margins in the trading of eight ASEAN-China Free Trade Area (Indonesia, Malaysia, Singapore, Thailand, Philippines, Vietnam, Cambodia, and China) against 10 trade partner countries (United States, Australia, India, Japan, Canada, South Korea, Pakistan, Russia, New Zealand, and the European Union). This study uses a gravity model with panel data regression methods. In this study, the authors usea software STATA version 13 for the data analysis process. 
This study uses secondary data obtained from various sources online. The export data obtained from the United Nations Commodity Trade Statistics Database (UN Comtrade) based classification code Harmonized System (HS) six-digit. Data port efficiency is obtained from the Global Competitiveness Report. GDP per capita and population was obtained from the World Development Indicator (WDI). Distance data between countries obtained from the Centre d'études prospectives et d'Informations Internationales (CEPII).

The operational definition of each variable used in this study are as follows:

\section{Extensive Margin (EMij)}

Extensive margin is one source of export growth can be defined as a weighted sum of the category (product) exported by exporting countries to importing countries compared to the category that are exported by the whole world to the importing countries. Extensive margin is also often referred to as a variation of export. Extensive margin data is then converted into natural logarithms.

\section{Intenisve Margin (EMij)}

Intensive margin is one source of export growth is defined as the total value of exports of the exporting countries compared with the total export value all over the world in a set of categories of products exported by exporting countries to importing countries. Data intensive margin is then converted into natural logarithms.

\section{Port Efficiency $\left(P E_{i}, P E_{j}\right)$}

Port efficiency is defined as a measure of the quality of port infrastructure and airports. Measurement of port efficiency is done by using the average value of the index of quality of port infrastructure and the quality of the water infrastructure index. Data port efficiency is then converted into natural logarithms.

\section{Gross Domestic Product per Capita $\left(\mathrm{GDPPC}_{\mathrm{i}}, \mathrm{GDPPC}_{\mathrm{j}}\right.$ )}

Gross Domestic Product per Capita (GDPPC) is the value of GDP of a countrythat has been divided by the population of the country. GDP per capita is used as a proxy of the size of the economy of a country. In this study, GDP per capita that is used is the GDP per capita to the base year 2005 in units of US \$. GDP per capita is comprised of GDP per capita exporter and importer countries. GDP per capita data is then converted into natural logarithms.

\section{Population $\left(\mathrm{POP}_{\mathrm{i}}, \mathrm{POP}_{\mathrm{j}}\right.$ )}

Population reflects the total number of people who live in a region. In this study, the population used is the population in the exporting countries and importing countries. Population data is then converted into natural logarithms.

\section{Distance (DIST $\left.T_{\mathrm{ij}}\right)$}

The distance is a proxy for transportation costs which must be issued by a state when trading with other countries. The distance used in this research is the distance between the capital exporting countries with capital importers countries. The distance used in this study is expressed in unit kilometer $(\mathrm{km})$. Distance data is then converted into natural logarithms.

\section{Panel Data Regression Methods}

Panel data regression model can be estimated using three methods: Pooled Least Square (PLS), Fixed Effects Model (FEM), and Random Effects Model (REM).

\section{Pooled Least Square}

Pooled Least Square is an analytical technique that combines cross section data and time 
series data. This approach does not pay attention to individual dimensions and time so it is assumed that the data behavior between individuals within the same research in various periods of time. In this model estimation is done using Ordinary Least Square (OLS) (Ariefianto \& Sallama, 2012: 149). Model pooled least square regression equation can be written as follows:

$$
Y_{i t}=\beta_{1}+\beta_{2} X_{2 i t}+\beta_{3} X_{3 i t}+\ldots \beta_{n} X_{n i t}+u_{i t}
$$

\section{Fixed Effect Model}

Fixed effect model is a method of inserting a dummy variable to capture the change in the intercept between individuals and across time. This method is based on the difference between the intercept but interceptnya same cross section over time. Additionally, the model also assumes that the regression coefficient (slope) remains between the cross section and across time (Agus, 2009: 232-233). Regression model fixed effect model can be written as follows:

$$
Y_{i t}=\alpha_{1}+\alpha_{2} D_{2}+\ldots+\alpha_{n} D_{n}+\beta_{2} X_{2 i t}+\ldots \beta_{n} X_{n i t}+u_{i t}
$$

\section{Random Effect Model}

Random Effect Model is a method that uses a variable disturbance (error terms) inestimating panel data to solve problems on the fixed effect model. This method of selecting panel data estimation where variable disturbance (error terms) may be interconnected between individuals and across time. This method performs estimationusing generalized least squares (GLS) (Agus, 2009: 235). Regression model random effect model can be written as follows:

$$
Y_{i t}=\beta_{1}+\beta_{2} X_{2 i t}+\ldots+\beta_{n} X_{n i t}+\varepsilon_{i t}
$$

\section{Selection Estimation Model in Panel Data}

To determine the most appropriate estimation technique in estimating panel data will be conducted three tests. First, using the $\mathrm{F}$ test statistic to choose between pooled least square (PLS) or fixed effect model (FEM). Second, use the Hausman test to choose between a fixed effect model (FEM) or random effects model (REM). Third, using the Lagrange Multiplier test to choose between pooled least square (PLS) or random effects model (REM).

\section{Results and Discussion}

This study uses panel data which is a combination of cross section data and time series data. Panel data can be estimated using three methods, is Pooled Least Square, Fixed Effect Model and Random Effect Model. The determination of the best method to use can be done using three types of testing: test F-Restricted, Hausman test, and the test panel data regression Multiplier.

Based on the test results of Lagrange Multiplier known that the best estimation model used is Random Effect Model. In this research, there are two dependent variables used in the estimation, is extensive and intensive margin margin. The estimation results by using Random Effect Model can be seen in Table 1. 
Table 1: Regression Results PLS, FEM, and REM

\begin{tabular}{ccccccc}
\hline \multirow{2}{*}{$\begin{array}{c}\text { Independen } \\
\text { Variables }\end{array}$} & \multicolumn{5}{c}{ Extensive Margin (In EM) } & \multicolumn{2}{c}{ Intensive Margin (In IM) } \\
\cline { 2 - 6 } & PLS & FEM & REM & PLS & FEM & REM \\
\hline Ln PEit & 0,0692326 & $0,866777^{*}$ & $0,5195858^{*}$ & $1,813105^{*}$ & 0,3112354 & 0,4701066 \\
\hline Ln PEjt & $(0,25)$ & $(2,59)$ & $(1,74)$ & $(5,55)$ & $(0,92)$ & $(1,49)$ \\
\hline & $0,8690027^{*}$ & 0,63735 & 0,7351707 & $1,708243^{*}$ & 0,4977025 & $0,8299991^{* *}$ \\
\hline Ln GDPPCit & $(2,83)$ & $(1,17)$ & $(1,64)$ & $(4,65)$ & $(0,90)$ & $(1,71)$ \\
\hline & $0,638171^{*}$ & $-0,058719$ & $0,5240217^{*}$ & $0,5100631^{*}$ & $0,8288153^{*}$ & $0,6018272^{*}$ \\
\hline Ln GDPPCjt & $(12,67)$ & $(-0,26)$ & $(6,84)$ & $(8,45)$ & $(3,59)$ & $(6,82)$ \\
\hline 0,218499* & 0,1182385 & $0,2200083^{*}$ & $-0,132515^{*}$ & 0,0789647 & $-0,1101545$ \\
\hline Ln POPit & $(6,70)$ & $(0,35)$ & $(3,28)$ & $(-3,39)$ & $(0,23)$ & $(-1,36)$ \\
\hline & $0,375031^{*}$ & $1,311307^{*}$ & $0,3765822^{*}$ & $0,675842^{*}$ & $-0,8297295$ & $0,5780974^{*}$ \\
\hline Ln POPjt & $(20,37)$ & $(2,27)$ & $(8,50)$ & $(30,63)$ & $(-1,41)$ & $(10,45)$ \\
\hline & $0,150818^{*}$ & 0,9615993 & $0,1459353^{*}$ & $-0,069033^{*}$ & $-1,39272^{* *}$ & $-0,1201737^{*}$ \\
\hline Ln DISTij & $(8,06)$ & $(1,19)$ & $(3,05)$ & $(-3,08)$ & $(-1,70)$ & $(-2,00)$ \\
\hline & $-0,127277^{*}$ & 0 & $-0,1156974$ & $-0,503749^{*}$ & 0 & $-0,4837605^{*}$ \\
\hline R-Squared & $(-2,45)$ & $(0 m i t t e d)$ & $(-0,85)$ & $(8,09)$ & $(0 m i t t e d)$ & $(-5,79)$ \\
\hline
\end{tabular}

Note: Processing Results STATA 13

Sign *: Significant at 5\%, Sign ** : Significant at $10 \%$

The estimated model using Random Effect Model for the extensive margin (InEM) are: $\ln E M_{i j t}=-17.60085+0.5195858 \ln \left(P E_{i t}\right)+0.7351707 \ln \left(P E_{j t}\right)+$

$$
\begin{aligned}
& 0.5240217 \ln \left(G D P P C_{i t}\right)+0.2200083 \ln \left(G D P P C_{j t}\right)+ \\
& 0.3765822 \ln \left(P O P_{i t}\right)+0.145935 \ln \left(P O P_{j t}\right)-0.1156974 \ln \left(D I S T_{i j}\right)+\varepsilon_{i t}
\end{aligned}
$$

Meanwhile, the model estimates using Random Effect Model for intensive margin (IM) is:

$$
\begin{aligned}
\ln I M_{i j t}= & -13.73681+0.4701066 \ln \left(P E_{i t}\right)+0.8299991 \ln \left(P E_{j t}\right)+ \\
& 0.6018272 \ln \left(G D P P C_{i t}\right)-0.1101545 \ln \left(G D P P C_{j t}\right) \\
& +0.5780974 \ln \left(P O P_{t}\right)-0.1201737 \ln \left(P O P_{j t}\right)-0.4837605 \ln \left(D I S T_{i j}\right)+\varepsilon_{i t}
\end{aligned}
$$

\section{Effect of Trade Facilitation and Variable Gravity Model On Extensive Margin}

Port efficiency exporting countries have positive and significant impact on the extensive margin ACFTA member countries. It shows that an increase in trade facilitation indicated by an increasingly efficient ports and airports cause the higher the level of extensivemargin ACFTA member states. An efficient port and airport will cause a reduction intransport costs which must be issued by exporters thereby increasing the level of diversity of goods exported by a country.

Improved port efficiency of a country indicates increased levels of trade facilitation that country. Increased trade facilitation would reduce trade costs, creating opportunities for new trade. A decrease in trade costs will cause companies that previously did not perform export activity because it has a low productivity began to enter the export market (Beverelli et al., 2015). The increasing number of companies to enter the export market will lead to the types of goods exported by a country becomes more diversified. It is based on the assumptionMelitz which states that each company produces different types of goods to one another (Dennis \& Shepherd, 2011). 
Port efficiency importing countries do not have a significant effect on the extensive margin. It shows that improvement of the efficiency of ports and airports in the country trading partners do not provide significant impact on the level of diversity of the types of goods exported by the country members of the ACFTA.

GDP per capita exporters have a positive and significant impact on the extensive margin ACFTA member countries. It shows that the improvement of GDP per capita exporting countries will increase the level of diversity of the types of goods exported by the country members of the ACFTA.

According to Chaney (2018) that of distance remains mysterious. I offer an explanation for the role of distance: If ( $i$, improvement of the size of the economy of a country exporters will increase the number of companies that exist in the country so that the country's production levels will also increase. According to Dennis \& Shepherd (2011), the more the number of companies that exist in a country will cause more varied also the type of goods exported by the country (extensive margin). It is based on the assumption Melitz which statesthat each company produces different types of goods.

GDP per capita importer countries have positive and significant impact on the extensive margin ACFTA member countries. It means that the improvement of GDP per capita importing countries will increase the level of diversity of the types of goods exported by the country members of the ACFTA. Increased GDP per capita importing countries led to increased purchasing power of people in these countries so that the demand for commodities produced by other countries increases.

According to Krugman et al. (2012), countries with greater economic size tend to have the value of imports in large quantities anyway. Appleyard and Field (2014: 195) also states that the higher the level of income in importing countries led to consumers in importing countries buy more kinds of goods from exporting countries.

Population of the exporting countries have positive and significant impact on the extensive margin ACFTA member countries. This suggests that the increase in population would increase the level of diversity of goods exported by the country members of the ACFTA. An increase in population will cause the level of production in the exportingcountries increased so that the type of goods produced more diversified.

Population of the importing country is positive and significant impact on the extensive margin ACFTA member countries. This means that an increase in population importing countries will increase the level of diversity of the types of goods exported by the country members of the ACFTA. An increase in population in the importing country means that demand for goods exported from other countries has increased. In addition, differences in the tastes and preferences of consumers led to the type of goods demanded by importing countries become more varied.

The distance between the exporters with the importing country does not have asignificant effect on the extensive margin. It shows the distance between the ACFTA member countries with trade partner countries do not provide a significant influence on the level of diversity of the types of goods exported by the country members of the ACFTA.

Cheong et al. (2016) states that the rapid progress of the Internet and e-commerce in the last decades have caused the cost of information and set-up costs reduced. This causes the exporters can increase the degree of variation of export (extensive margin), so that the effectof distance on the extensive margin is diminishing all the time.

\section{Effect of Trade Facilitation and Variable Gravity Model On Intensive Margin}

Port efficiency exporting countries do not have a significant effect on the intensive margin ACFTA member countries. This means that an increase port efficiency ACFTA member 
states do not provide a significant impact on the volume of exports of ACFTA member countries.

Port efficiency importing countries have a positive and significant impact on the intensive margin ACFTA member countries. It shows that improvement of trade facilitation in countries that import more impact on export volume compared to the level of diversity of the types of goods exported by the country ACFTA. Increased efficiency of ports and airportsin the importing country will result in trading costs which must be issued by the exporters is reduced thereby increasing the country's export volume exporter.

Improved port efficiency in importing countries will cause trade costs which must be issued by exporters is reduced. According Türkchan (2014), low trading costs led to the existing exporters increase the volume of sales of goods for export. This causes the level of margin intensive exporting countries have increased.

GDP per capita exporting countries have a significant influence on the intensive margin ACFTA member countries. It shows that the increase in GDP per capita exporting countries will increase the volume of goods exported by the country. Increased GDP per capita exporters led to increased production capacity in the exporting countries produce export goods so that the volume of exports also increased.

GDP per capita is a proxy of economic size of a country. Chaney (2018) that of distance remains mysterious. I offer an explanation for the role of distance: If ( $i$ declared that the improvement of the size of the economy of a country exporters will increase the number of companies that exist in the country so that the country's production levels will also increase. Increased production levels state will increase the ability of the country's exports. Therefore, the volume of exports (intensive margin) of the country also increased.

GDP per capita importing countries do not have a significant influence on the level of intensive margin ACFTA member states. It shows that the country's economic size of trading partners do not provide significant impact on the volume of exports of ACFTA member countries. These results are not in line with the research Feenstra and Ma (2014) which states that the improvement of GDP per capita importer country that is a proxy of economic size importing countries will increase the level of intensive margin.

Population of exporting countries have positive and significant impact on the intensive margin ACFTA member countries. This suggests that the increase in population would increase the volume of goods exported by the country members of the ACFTA. An increase in population will cause the level of production in exporting countries increased so that the volume of goods exported also increased.

Population of the importing country has a negative and significant impact on the intensive margin ACFTA member countries. This means that an increase in populationimporting countries will reduce the volume of exports of ACFTA member states. Yang \& Martinez-Zarzoso (2014) states that the population tends to correlate negatively on trade flows because of a large population showed a large domestic market, resources are richer and more varied output. An increase in population in importing countries led to increase the production capability of the country so that the level of output is generated also increases. The increasein output led to a state able to meet domestic demand so that these countries tend to reduce dependence on the output produced by other countries.

The distance between the exporters with the importing country has a negative and significant impact on the intensive margin ACFTA member countries. This means that the greater the distance between exporting countries to importing countries, it will cause adecrease in export volume ACFTA member states. The distance between the exporters with the importing country related to the transport costs which must be issued a country in conducting international trade. The farther a distance between countries, the trade costs incurred great- 
er, causing the volume of exports also reduced.

\section{Conclusion}

Based on the research that has been described, it can be concluded as follows:

1. Port efficiency exporting countries have positive and significant impact on the level ofextensive margin, while port efficiency importing country does not have a significant influence on the level of extensive margin ACFTA member country in 2006-2014.

2. GDP per capita exporter and importer countries have a positive and significant impacton the level of extensive margin ACFTA member country in 2006-2014.

3. The population of the exporting countries and importing countries have a positive and significant impact on the level of extensive margin ACFTA member country in 2006- 2014.

4. The distance between the exporters with the importing country does not have asignificant influence on the level of extensive margin ACFTA member country in 2006-2014.

5. Port efficiency importing country has a positive and significant impact on the level of intensive margin, while port efficiency exporting countries do not have a significant influence on the level of intensive margin ACFTA member country in 2006-2014.

6. GDP per capita exporters have a positive and significant impact on the level of intensive margin, while the per capita GDP of the importing country does not have a significant influence on the level of intensive margin ACFTA member country in 2006-2014.

7. The population of the exporting countries have a positive and significant impact on the level of intensive margin, however the population of the importing country is a significant negative effect on the intensive margin tngkat ACFTA member country in 2006-2014.

8. The distance between the exporters with the importing country is a significant negative effect on the level of intensive margin ACFTA member country in 2006- 2014.

\section{References}

Head, K. (2003). Gravity for beginners. University of British Columbia, 2053.

Türkcan, K. (2014). Investigating the role of extensive margin, intensive margin, price and quantity components on Turkey's export growth during 1998-2011.

Agus, W. (2009). Ekonometrika Pengantar dan Aplikasinya, Edisi Ketiga. Yogyakarta: Ekonesia.

Aldan, A., \& Çulha, O. Y. (2016). The role of the extensive margin in export of Turkey: A comparative analysis. Central Bank Review, 16(2). https://doi.org/10.1016/j. cbrev.2016.05.002

Appleyard, D. R., \& Field, A. J. (2014). International Economics. 8th Edition. New York:McGraw Hill

Ariefianto, M. D., \& Sallama, N. I. (2012). Ekonometrika: Esensi dan Aplikasi Dengan Menggunakan EViews. Erlangga.

ASEAN Secretariat. (2015). ASEAN Statistics Leaflet-Selected Key Indicators. https://www. aseanstats.org/publication/asean-statistics-leaflet-selected-key-indicators-2015/

Baier, S. L., Bergstrand, J. H., \& Feng, M. (2014). Economic integration agreements and the margins of international trade. Journal of International Economics, 93(2). https://doi. org/10.1016/j.jinteco.2014.03.005 
Beverelli, C., Neumueller, S., \& Teh, R. (2015). Export Diversification Effects of the WTO Trade Facilitation Agreement. World Development, 76. https://doi.org/10.1016/j.worlddev.2015.07.009

Chaney, T. (2018). The gravity equation in international trade: An explanation. Journal of Political Economy, 126(1). https://doi.org/10.1086/694292

Cheong, J., Kwak, D. W., \& Tang, K. K. (2016). The distance effects on the intensive and extensive margins of trade over time. Empirical Economics, 50(2). https://doi.org/10.1007/ s00181-015-0927-x

Dennis, A., \& Shepherd, B. (2011). Trade facilitation and export diversification. World Econo$m y, 34(1)$. https://doi.org/10.1111/j.1467-9701.2010.01303.x

Dutt, P., Mihov, I., \& Van Zandt, T. (2013). The effect of WTO on the extensive and the intensive margins of trade. Journal of International Economics, 91(2). https://doi. org/10.1016/j.jinteco.2013.08.001

Feenstra, R. C., \& Ma, H. (2014). Trade facilitation and the extensive margin of exports. Japanese Economic Review, 65(2). https://doi.org/10.1111/jere.12031

Hummels, D., \& Klenow, P. J. (2005). The variety and quality of a nation's exports. In American Economic Review (Vol. 95, Issue 3). https://doi.org/10.1257/0002828054201396

Krugman, P. R., Obstfeld, M., \& Melitz, M. J. (2012). International economics : theory and policy_9th edition. In Policy: Vol. New York,

Lee, H., \& Kim, C.-S. (2018). The Impact of Trade Facilitation on the Extensive and Intensive Margins of Trade: An Application for Developing Countries. SSRN Electronic Journal. https://doi.org/10.2139/ssrn.2318224

Li, Y., \& Wilson, J. (2009). Trade facilitation and expanding the benefits of trade: Evidence from firm level data. ARTNeT Working Papers.

Moïsé, E., \& Sorescu, S. (2013). Trade Facilitation Indicators: The potential impact of trade facilitation on developing countries. OECD Trade Policy Papers, 144.

Persson, M. (2013). Trade facilitation and the extensive margin. Journal of International Trade and Economic Development, 22(5). https://doi.org/10.1080/09638199.2011.587 019

Portugal-Perez, A., \& Wilson, J. S. (2012). Export Performance and Trade Facilitation Reform: Hard and Soft Infrastructure. World Development, 40(7). https://doi.org/10.1016/j. worlddev.2011.12.002

Salvatore, D. (2014). Ekonomi Internasional (9th ed.). Salemba Empat.

Wilson, J. S., Mann, C. L., \& Otsuki, T. (2005). Assessing the benefits of trade facilitation: A global perspective. World Economy, 28(6). https://doi.org/10.1111/j.14679701.2005.00709.x

Yang, S., \& Martinez-Zarzoso, I. (2014). A panel data analysis of trade creation and trade diversion effects: The case of ASEAN-China Free Trade Area. China Economic Review, 29. https://doi.org/10.1016/j.chieco.2014.04.002 